\title{
Effects of valsartan vs captopril on some renal function tests in hypertensive patients
}

\author{
Shamil Hashim Othman \\ Department of pharmacology, College of Medicine, Mosul, Iraq.
}

$\frac{\text { Received }}{22.2 .2011} \quad \frac{\text { Accepted }}{20.9 .2011}$

\section{ABSTRACT}

Objectives: To investigate the effects of valsartan and captopril on some renal function tests (RFTs) in patients with essential hypertension.

Patients and methods: A total of 40 patients with stage I essential hypertension were recruited and investigated for RFTs which include, blood urea, serum creatinine, creatinine clearance, serum sodium and serum potassium. The patients were divided into 2 groups, namely the valsartan group which consisted of 20 patients and the captopril group which consisted of 20 patients. The patient groups were followed- up for 8 weeks during which RFTs were measured before starting therapies and at the end of the follow-up period using commercially available kits. The patient groups were compared with a control group consisted of 30 apparently healthy subjects.

Results: The RFTs at baseline in both patient groups were found elevated as compared to the control group $(p<0.001)$, except for serum potassium concentration which was comparable. The RFTs in patient groups were comparable before and after therapies.

Conclusion: The use of valsartan and captopril for 8 weeks in hypertensive patients has no adverse effects on RFTs.

Keywords: Hypertension, valsartan, captopril, renal function tests.

$$
\begin{aligned}
& \text { الخلاصة } \\
& \text { أهداف الدراسة: لدر اسة تأثير عقاري الفالزرتان و الكابتوبريل على اختبار ات وظائف الكلى لدى المرضى الألى }
\end{aligned}
$$

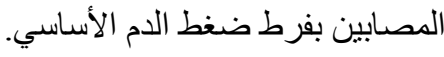

$$
\begin{aligned}
& \text { المرضف ولرالق العلى:شملت الدرلسة على أربعين مريضا مصابا بفرط ضغط الدم الأساسي من الدرجة }
\end{aligned}
$$

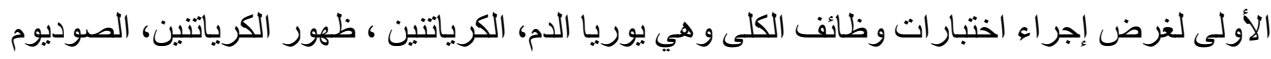

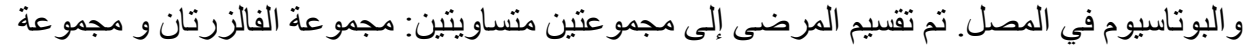

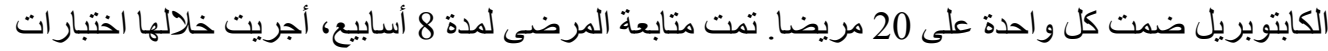

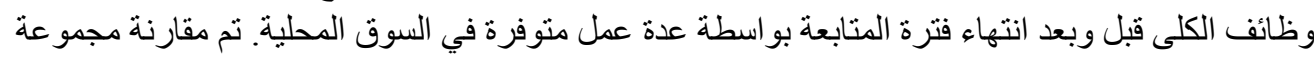

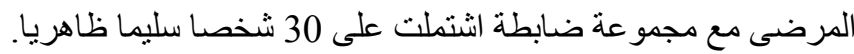



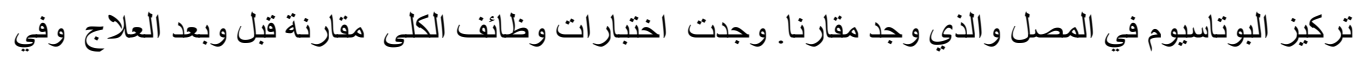

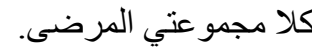



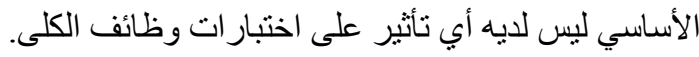


$\mathrm{T}$ he exact prevalence of chronic kidney disease is unknown, but current estimates based on a community-based survey which was conducted on a nationally representative sample with the aid of WHO step wise approach done in Iraq in 2006, showed that the prevalence of hypertension was $40.4 \%$ while that for diabetes was $6.5 \%$ among permanent household of 25-65 years. Both hypertension and diabetes represent important risk factors for the development of chronic kidney diseases ${ }^{1}$. One of the most significant health consequences of chronic kidney disease is end-stage renal disease (ESRD), of which $23 \%$ of cases in 1999 were judged by nephrologists to be caused by hypertension ${ }^{2}$. Despite the availability and widespread use of antihypertensive medication, elevated BP continues to be a major contributor to chronic kidney disease and the leading cause of ESRD in AfricanAmericans $^{3}$. A high-normal serum creatinine level in an untreated patient with hypertension should be regarded not only as a risk factor for renal failure but as an important sign of target organ damage ${ }^{4}$.

There is unequivocal evidence that lowering elevated BP slows the progression of renal disease, especially in patients with proteinuria ${ }^{5}$. The national kidney foundation-kidney disease outcomes quality initiative working group guidelines indicate that the goals of antihypertensive therapy in patients with chronic kidney disease are to decrease blood pressure, as well as slow the progression of kidney disease and reduce the risk of cardiovascular disease ${ }^{6}$.

The renin angiotensin aldosterone system (RAAS) has various direct and indirect actions on the kidney that modify systemic BP homeostasis and regulate intravascular volume status. Activation by Angiotensin II of the AT1 receptors present in the kidney stimulates a variety of effects in humans, including modulation of renal vasomotor tone, control of endocrine functions and regulation of cellular growth and proliferation ${ }^{7}$. However, unregulated and excessive production of Angiotensin II is associated with renal injury that can become progressive and irreversible. Examples of this phenomenon include both diabetic and non-diabetic nephropathies ${ }^{8,9}$. Angiotensin converting enzyme inhibitors (ACEIs) and angiotensin receptor blockers (ARBs) have favorable effects on the progression of diabetic and nondiabetic renal disease ${ }^{10}$.

Captopril is an ACEIs $^{11}$ act by suppressing renin angiotensin system by inhibiting ACE which is widely distributed in the circulation and tissues. This action decreases the formation of a potent vasoconstrictor, angiotensin II, and slows the degradation of the potent vasodilator, bradykinin $^{12}$. Valsartan is an ARBs ${ }^{13}$ act by inhibiting the binding of formed angiotensin II to its receptors ${ }^{14}$. Both these 2 drugs reduce the activity of the RAAS and thus increasing renal blood flow and glomerular filtration rate through dilating the efferent arterioles and reducing the intraglomerular pressure. 
Many basic studies and clinical studies in humans have now shown that inhibition of the RAAS reduces the injurious effects of Angiotensin II (constricts both afferent and efferent arterioles, stimulate mesangial cell contraction, stimulate the release of aldosterone and mediate proliferative effects involved in atherosclerosis) in diabetic and non-diabetic nephropathies ${ }^{7}$. Thus the present study was undertaken to investigate the effects of valsartan and captopril on some kidney function parameters in a number of hypertensive patients.

\section{Patients and methods}

Forty newly diagnosed essential hypertensive patients were participated in this study. The patients were divided into 2 groups of equal numbers. Group 1 consisted of 20 patients, whose ages mean is $44 \pm 8.6$ years and involved 10 males and 10 females. They were kept on captopril therapy (Rilcaptone tablets, Cyprus) in a dose of 25 to 50 mg two to three times daily. Group 2 consisted of 20 patients whose age mean is $45.2 \pm 8.6$ years and involved 10 males and 10 females. They were kept on valsartan therapy (Univan capsules, Syria ) in a dos of 80 to 160 mg once daily.

Inclusion criteria including newly diagnosed, hypertensive patients having stage I hypertension according to JNS-7 categories ${ }^{10}$.Exclusion criteria including patients with a history of hepatic diseases, cardiac diseases or diabetes mellitus. Patients on antihypertensive therapy or any drug that affects blood pressure. Patients having hypersensitivity to ACE inhibitors or ARBs. Patients with a history of severe hypertension (Stage $\Pi)$, according to NJC-7 categories ${ }^{10}$. Thirty apparently healthy normotensive individuals, whose mean of ages was $43.8 \pm 7.4$ years, were used as a control group.

Before and at the end of treatment, $5 \mathrm{ml}$ blood samples were withdrawn from each patient and control subject. The serum of the blood samples were used to estimate kidney function parameters immediately after the withdraw of blood. Blood pressure was measured for each subject by standard mercury sphygmomanometer from the arm at the sitting position. Measurement was performed after at least 5 minutes of rest at the morning between 9.00 to 11.00 A.M. Blood pressure was measured at baseline and every 2 weeks for 2 months duration during treatment with captopril or valsartan.

Serum urea concentration is determined by the enzymatic method by using a kit provided by Biomerieux (France). Estimation of serum creatinine concentrations was based upon Jaffe reaction by using a kit provided by Syrbio company (France). Estimation of creatinine clearance is made by using the equation of Cockroft and Gault ${ }^{15}$. Determination of sodium and potassium concentrations were done by using flame photometer $^{16}$.

Unpaired t-test was used to compare between age and sex and kidney parameters of the control and the patient groups. Paired t-test was used to compare between the studied kidney parameters before and after therapy with captopril or valsartan. 
Results were considered significant at $p$ value equal or less than 0.05 (17).

\section{Results}

Age and sex distribution of the patients and the control were appeared in Table 1. The patients and the controls are matched regarding age and sex distribution with non significant values ( $p=0.93$ and 0.56 regarding age and $p=0.37$ and 0.21 regarding sex for valsartan and captopril respectively ).

Blood urea, serum creatinine concentration, creatinine clearance and serum sodium concentration of the patients at baseline (before drug administration of the two groups) were significantly elevated at $p \leq 0.001$ as compared with control group while there was no significant differences between potassium concentration of the patient' and control' groups as shown in tables 2 and 3.

Comparison of the studied parameters before and after therapy with captopril or valsartan showed non significant differences at $p \leq 0.001$ for all studied parameters as shown in Tables 4 and 5 .

Table 1. Characteristics of hypertensive patients and control group

\begin{tabular}{|c|c|c|c|c|c|c|c|}
\hline Groups & Parameters & \multicolumn{4}{|c|}{ Mean \pm SD } & \multicolumn{2}{|c|}{$P$-Value } \\
\hline Control & Age (Year) & \multicolumn{4}{|c|}{$43.8 \pm 7.4$} & & \\
\hline Valsartan & Age (Year) & \multicolumn{4}{|c|}{$45.2 \pm 8.6$} & \multicolumn{2}{|c|}{$0.93 * * *$} \\
\hline \multirow[t]{3}{*}{ Captopril } & Age (Year) & \multicolumn{4}{|c|}{$44.0 \pm 8.6$} & \multicolumn{2}{|c|}{$0.56 * * *$} \\
\hline & & \multicolumn{2}{|c|}{ Control } & \multicolumn{2}{|c|}{ Valsartan } & \multicolumn{2}{|c|}{ Captopril } \\
\hline & & No. & $\%$ & No. & $\%$ & No. & $\%$ \\
\hline \multirow{4}{*}{ Sex } & Male & 15 & 50.0 & 10 & 50.0 & 10 & 50.0 \\
\hline & Female & 15 & 50.0 & 10 & 50.0 & 10 & 50.0 \\
\hline & Total & 30 & 100 & 20 & 100 & 20 & 100 \\
\hline & $P$ - Value & & & \multicolumn{2}{|c|}{$0.37 * * *$} & \multicolumn{2}{|c|}{$0.21 * * *$} \\
\hline
\end{tabular}

*** Non Significant difference from control at $\mathrm{p} \leq 0.001$ 
Table 2. Comparison of renal function tests between control group and captopril (before) therapy

\begin{tabular}{|l|l|l|}
\hline \multirow{2}{*}{ Parameters } & \multicolumn{2}{|l|}{ Mean $\pm \mathrm{SD}$} \\
\cline { 2 - 3 } Blood Urea & Control $(\mathrm{n}=40)$ & Before $(\mathrm{n}=50)$ \\
\hline Serum Creatinine & $3.40 \pm 0.90$ & $4.47 \pm 0.63^{* * *}$ \\
\hline Cr. Clearance & $92.97 \pm 9.4$ & $86.75 \pm 17.23^{* * *}$ \\
\hline S. $\mathrm{Na}^{+}$ & $127.40 \pm 4.97$ & $137.3 \pm 3.04^{* * *}$ \\
\hline S. $\mathrm{K}^{+}$ & $4.00 \pm 0.6$ & $4.02 \pm 0.56^{*}$ \\
\hline
\end{tabular}

*** Significant difference from control at $\mathrm{p} \leq 0.001$

* Non- significant difference from control at $p \leq 0.001$

Table 3. Comparison of renal function tests between control group and Valsartan (before) therapy

\begin{tabular}{|c|c|c|}
\hline \multirow{2}{*}{ Parameters } & \multicolumn{2}{|c|}{ Mean \pm SD } \\
\cline { 2 - 3 } Blood Urea & Control $(\mathrm{n}=30)$ & Before $(\mathrm{n}=20)$ \\
\hline Serum Creatinine & $3.4 \pm 0.90$ & $4.67 \pm 0.99^{* * *}$ \\
\hline Cr. Clearance & $92.97 \pm 9.4$ & $82.2 \pm 15.40^{* * *}$ \\
\hline S. Na & $127.40 \pm 4.97$ & $94.45 \pm 13.84^{* * *}$ \\
\hline S. $\mathrm{K}^{+}$ & $4.00 \pm 0.60$ & $136.6 \pm 4.00^{* * *}$ \\
\hline
\end{tabular}

*** Significant difference from control at $\mathrm{p} \leq 0.001$

$*$ Non- significant difference from control at $\mathrm{p} \leq 0.001$ 
Table 4. Comparison of renal function tests in valsartan group therapy

\begin{tabular}{|c|c|c|c|}
\hline Parameters & Groups & Mean \pm SD & $p$-value \\
\hline \multirow{2}{*}{ Blood Urea } & Before & $4.67 \pm 0.00$ & \multirow{2}{*}{ NS } \\
\hline & After & $4.81 \pm 0.87$ & \\
\hline \multirow{2}{*}{ S. Creatinin } & Before & $82.2 \pm 15.4$ & \multirow{2}{*}{ NS } \\
\hline & After & $82.5 \pm 14.10$ & \\
\hline \multirow{2}{*}{ Cr. Clearance } & Before & $94.45 \pm 13.84$ & \multirow{2}{*}{ NS } \\
\hline & After & $94.1 \pm 13.40$ & \\
\hline \multirow{2}{*}{ S. $\mathrm{Na}^{+}$} & Before & $136.6 \pm 4.00$ & \multirow{2}{*}{ NS } \\
\hline & After & $136.4 \pm 3.34$ & \\
\hline \multirow{2}{*}{ S. $\mathrm{K}^{+}$} & Before & $4.17 \pm 0.6$ & \multirow{2}{*}{ NS } \\
\hline & After & $4.10 \pm 0.58$ & \\
\hline
\end{tabular}

$\mathrm{NS}=$ Non- significant

Table 5. Comparison of renal function tests in captopril group (before \& after) therapy

\begin{tabular}{|c|c|c|c|}
\hline Parameters & Groups & Mean \pm SD & $p$-value \\
\hline \multirow{2}{*}{ Blood Urea } & Before & $4.47 \pm 0.63$ & \multirow{2}{*}{ NS } \\
\hline & After & $4.49 \pm 0.58$ & \\
\hline \multirow{2}{*}{ S. Creatinin } & Before & $86.75 \pm 17.23$ & \multirow{2}{*}{ NS } \\
\hline & After & $86.10 \pm 15.50$ & \\
\hline \multirow{2}{*}{ Cr. Clearance } & Before & $97.98 \pm 9.68$ & \multirow{2}{*}{ NS } \\
\hline & After & $96.70 \pm 9.5$ & \\
\hline \multirow{2}{*}{ S. $\mathrm{Na}^{+}$} & Before & $137.3 \pm 3.04$ & \multirow{2}{*}{ NS } \\
\hline & After & $137.15 \pm 2.96$ & \\
\hline \multirow{2}{*}{ S. $\mathrm{K}^{+}$} & Before & $4.02 \pm 0.56$ & \multirow{2}{*}{ NS } \\
\hline & After & $3.97 \pm 0.54$ & \\
\hline
\end{tabular}

$\mathrm{NS}=$ Non- significant 


\section{Discussion}

The present study revealed that the measured renal parameters are higher in hypertensive patients as compared with control group. This is may be attributed to alterations in the renal auto regulation due to endothelial dysfunction which lead to impaired vasodilatation of the afferent arteriole in response to alteration in arterial blood pressure (BP). These findings are in accordance with the results of Perticone et al. ${ }^{18}$ and Coresh et al. ${ }^{19}$ who demonstrated that elevated serum creatinine level, an indicator of chronic renal disease, is common and strongly related to inadequate treatment of high blood pressure. He and Whelton ${ }^{20}$ showed that many observational epidemiologic studies and randomized controlled trials have demonstrated that systolic blood pressure is an independent and strong predictor of risk of cardiovascular and renal disease.

The present study showed that administration of captopril or valsartan for eight weeks to hypertensive patients has resulted in good control of the BP in all patients based on the records of $\mathrm{BP}$ during the follow-up period and both these two drugs produced no adverse effects on the measured renal parameters as shown by the insignificant changes in these parameters. Many previous studies demonstrated that the administration of antihypertensive drugs in patients with hypertension have different effects on the kidneys. Our results are in agreement with Dimitry et $\mathrm{al}^{21}$, Pablo et $\mathrm{al}^{22}$ and Heffner et al ${ }^{23}$. Those authors found that the administration of captopril for hypertensive patients for 6 weeks did not show significant effects on serum urea, serum creatinin and creatinin clearance. Captopril in the current study produced no effects on serum sodium and potassium which goes in agreement with the results of Giasuddin et $\mathrm{al}^{24}$ who reported that significant sodium and potassium disturbances rarely occurred in hypertensive patient kept on captopril without renal or cardiac failure. Regarding the effects of valsartan on the studied parameters, the obtained results are in accordance with those of Watanabe et al. ${ }^{25}$ and Plum et al. ${ }^{26}$ who showed that the angiotensin II receptor blocker, valsartan, is able to improve renal function by reducing renal vascular resistance in hypertensive patients, especially in patients with microalbuminurea, and may prevent future renal failure in patients with essential hypertension. Our results are in accordance with those of Shahanz et al. ${ }^{27}$ and Priscilla et al 28 who demonstrated that angiotensin II receptor antagonists (losartan) have no effects on renal function as shown by the neither rise in serum creatinine nor decrease in creatinine clearance during the administration of the drug. In comparison between two drugs and in agreement with our results, Lacourciere et al ${ }^{29}$ showed the beneficial effects of losartan and enalapril on preserving renal function by decreasing urea, creatinine and increasing creatinine clearance.

In conclusion: the use of captopril or valsartan in patients with hypertension for 8 weeks produces no adverse effects on renal function tests and both drugs can be used safely 
because of their renoprotective effects and smooth control of the blood pressure.

\section{References}

1. WHO EMRO. Chronic noncommunicable diseases risk factors survey in Iraq. Ministry of health and ministry of planning and development cooperation, in collaboration with WHO;2006:158.

2. US Renal Data System (USRDS) 2002 Annual Data Report: Atlas of End Stage Renal Disease in the United States. Bethesda MD: National Institutes of Health, National Institute of Diabetes and Digestive and Kidney Diseases; 2002.

3. He J, Whelton PK. Elevated systolic blood pressure and risk of cardiovascular and renal disease: overview of evidence from observational epidemiologic studies and randomized controlled trials. Am Heart J 1999;138 (2):211-19.

4. Iseki K, Ikemiya Y, Fuliyama K. Risk factors of end-stage renal disease and serum creatinine in a community-based mass screening. Kidney Int. 1997;51:850-854.

5. Makki DD, Ma JZ, Louis TA, Kasiski BL. Long-term effects of antihypertensive agents on proteinuria and renal function. Arch Intern Med1995;155:107380.

6. Fan-Fan H. Pharmacologic intervention of hypertension in proteinuric chronic kidney disease: how and what. Chinese medical J 2008; 121:840-3.
7. Brewster UC, Perazella MA. Cardiorenal effects of the renninAngiotensin Aldostwrone system. Hospital Physician 2004;40:11-20.

8. Praving HH. Diabetic nephropathy: prevention and treatment. Kidney Int 2001; 60: 2041-55.

9. Jacobson HR. Chronic renal failure: pathophysiology. Lancet 1991;338:419-23.

10. Chobanian AV, Bakris GL, Black HR, et al. The Seventh report of the Joint National Committee on prevention, detection, evaluation and treatment of high blood pressure. JAMA 2003;289:256071.

11. Prabhu M, Palain S, Malhorta A, et al. Therapeutic dimensions of ACE inhibitors. A review of literature and clinical trials. Kath Univ Med J 2005;3:296-304.

12. Cheung BMY. Blockade of the rennin angiotensin system. HKMJ 2002; 8:185-91.

13. Reid JL. Molecular specific effects of angiotensin II antagonists:clinical relevance to treating hypertension. J RAAS 2005;6:15-24.

14. Wenzel RR. Role of angiotensin II receptor blockers in cardiorenal disease. Curr D Ther 2006;1:47-54.

15. Cockroft DW, and Gault $\mathrm{MH}$. Prediction of creatinine clearance from plasma creatinine. Nephron 1967;16:31-41.

16. Bishop M, Fody F, and Schoeff L. In: Clinical chemistry: procedures, principles and correlation. Lippincott Williams New York, USA: $\mathrm{p}$ 302-3.

17. Kirkwood BR. Essentials of Medical Statistics. $1^{\text {st }}$ ed.1988; 
Blackwell scientific publication, Oxford,43-56.

18. Perticone F, Maio R, Tripepi G, et al. Endothelial dysfunction and mild renal insufficiency in essential hypertension. Circulation 2004;110:821-5.

19. Coresh J, Wei GL, McQuillan G, et al. Prevalence of high blood pressure and elevated serum creatinine level in the United States: findings from the third National Health and Nutrition Examination Survey (1988-1994). Arch Intern Med. 2001;161:120716.

20. He J, Whelton PK. Elevated systolic blood pressure as a risk factor for cardiovascular and renal disease. J Hypertens 1999;17 (Suppl 1):S7-S17.

21. Dimitry SR, Abd AL-Kader SS, Fadel MA, et al. The effects of ACE inhibitors (Benazepril, captopril, and ramipril) on blood pressure, left ventricular mass and function and on different laboratory indices. Egyp $\mathrm{H} \quad \mathrm{J}$ 1988;50:1-15.

22. Pablo I, Josep M, Sergio L, et al. Effects of captopril and amlodipine on intra renal hemodynamics in hypertensive patients. J Am Soc Nephrol 2001;12:822-7.

23. Haffiner CA, Kendall MJ, Struthers AD, et al. Effect of captopril and enalpril on renal function in elderly patients chronic heart failure. Postgrad Med J 1995;71:287-92.
24. Giassudin AS, Adesanya CO, Isah AS. Serum electrolytes and calcium status in Nigerian patients with essential hypertension. J Islamic Acad Sci 1991;4(3):253-6.

25. Watanabe S, Okura T, Kurata M, et al. Valsartan reduces serum cystatin $\mathrm{c}$ and the renal vascular resistance in patients with essential hypertension. Clin Exp Hypertens 2006; 28: 451-61.

26. Plum J, Bunten B, Nemeth R, et al. Effects of angiotensin II antagonist valsartan on blood pressure, proteinuria, and renal hemodynamics in patients with chronic renal failure and hypertension. J Am Soc Nephrol 1998;9:2223-34.

27. Shahanz SH, Tania Z, Tultul A, et al. Losartan in patients with type 2 diabetes and proteinuria. Kidney International 2002;62:64-7.

28. Priscilla K, Kenneth F, David P. Randomized controlled crossover study of the effect on proteinuria and blood pressure of adding angiotensin II receptor antagonist to an angiotensin converting enzyme inhibitors in normotensive patients with chronic renal disease and proteinuria. Nephrol Dial Transplant 2002:597-560.

29. Lacourciere Y, Belanger A, Godin $\mathrm{C}$, et al. Long term comparison of losartan and enalapril on kidney function in hypertensive type 2 diabetics with early nephropathy. Kidney Int 2000;58:762-9. 